\title{
Serum and synovial survivin in rheumatoid arthritis: Relation to disease activity and severity Eman Baraka ${ }^{a}$, Mounir Serag El Din ${ }^{a}$, Ahmed El Shambky ${ }^{a}$, Nehad A. Fouad ${ }^{b}$, Mona Abdullah Abdelkader ${ }^{a}$
}

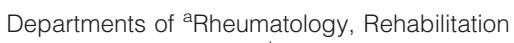 \\ and Physical Medicine, ${ }^{b}$ Medical Microbiology \\ and Immunology, Faculty of Medicine, Benha \\ University, Benha, Egypt \\ Correspondence to Eman Abdel Alim Baraka, \\ MD, Department of Rheumatology, \\ Rehabilitation and Physical Medicine, Benha \\ University Hospital, Elqalyubia, 13511, PO Box \\ 13518, Egypt. Tel: +20 1204000428 ; \\ fax: 0133227491; 0133213511; \\ e-mail: dremanbaraka@yahoo.com \\ Received 8 May 2019 \\ Accepted 30 June 2019
}

Egyptian Rheumatology \& Rehabilitation 2019, 46:221-228

\section{Background}

Rheumatoid arthritis (RA) is a progressive debilitating autoimmune disease, affecting $1 \%$ of the world population, leading to cartilage and bone destruction caused by insufficient apoptosis in the inflamed RA synovium. Survivin is a protooncogene biomarker known for its anti-apoptotic and cell cycle-regulating properties. Overexpression of survivin in non-cancerous processes has been linked to inflammation, presumably contributing to the decreased apoptosis in the $\mathrm{T}$ cells of the cerebrospinal fluid in multiple sclerosis, in skin lesions of patients with psoriasis and in synovial tissue of patients with RA.

\section{Aim of the work}

The aim of this study is to measure the serum and synovial levels of survivin and clarify their relations to disease activity, functional capacity, and radiographic damage in patients with RA.

\section{Patients and methods}

This study was carried out on 50 patients with RA who had a mean age of $46.4 \pm 10.94$ years. They were 39 females and 11 males. The control group was of matched age and sex, with a mean age of $46.03 \pm 10.53$ years and female: male ratio of $23: 7$. All patients were subjected to full history taking, thorough clinical examination, assessment of disease activity by disease activity score 28 activity score, and assessment of functional capacity and disability using Health Assessment Questionnaire. Plain radiographs of both hands of feet were done, scored and graded by Larsen score. Serum survivin from all the studied participants and survivin levels in the synovial fluid aspirated from 18 patients with RA who presented with knee effusion at the time of examination were measured by enzyme-linked immunosorbent assay, using a pair of matched anti bodies (R\&D systems, Abingdon, Uk).

Results

The mean serum survivin level was highly statistically significantly elevated $(P<0.001)$ in the sera of patients with RA than in the controls, being 239.1 \pm 115.15 and $77.03 \pm 30.20 \mathrm{pg} / \mathrm{ml}$, respectively. Synovial survivin levels ranged between 420 and $575 \mathrm{pg} / \mathrm{ml}$, with a mean of $479.61 \pm 52.68 \mathrm{pg} / \mathrm{ml}$, which was statistically significantly higher than the mean serum survivin level in patients with RA $(P<0.001)$. Patients were divided into survivin -ve group, which included 21 (42\%) of 50 patients with serum survivin less than $167.63 \mathrm{pg} / \mathrm{ml}$, and survivin +ve group, which included $29(58 \%)$ of 50 patients with RA with serum survivin more than or equal to $167.63 \mathrm{pg} / \mathrm{ml}$. Survivin +ve RA patients group had significantly longer mean disease duration $(P<0.001)$, Higher Health Assessment Questionnaire SCORE, and higher mean Larsen score $(P<0.001)$ than survivin -ve RA patients group. Overall, nine $(69.2 \%)$ of 13 RA patients with Sjogren's syndrome, eight $(80 \%)$ of 10 of the patients with pleural effusion, three $(50 \%)$ of six patients with Raynaud's phenomenon, and all patients with SC nodules (five, 100\%), episcleritis (two, 100\%), and vasculitis (one, 100\%) were survivin +ve. Larsen score in the patients with RA ranged from 0 to 65 , with a mean of 23.6 \pm 18.98 . Patients with RA who had Larsen score grading more than or equal to 2 (27/ $50,52 \%$ ) were considered to have an erosive RA disease. There were no statistically significant differences between patients with RA according to the presence of erosion regarding age, sex, visual analog scale values, disease activity score values, the presence of rheumatoid factor antibodies or anti-cyclic citrullinated peptides antibodies, the mean of hemoglobin \%, white blood cells count, platelets count, erythrocyte sedimentation rate first hour value, or the Creactive protein level. All patients with $\mathrm{RA}$ with erosive disease were survivin +ve and had statistically significantly elevated mean serum and synovial survivin levels than those patients with non erosive disease $(337.37 \pm 55.19$ vs. $126.78 \pm 24.33 \mathrm{pg} /$ $\mathrm{ml}$ and $422.5 \pm 3.53$ vs. $486.75 \pm 51.52 \mathrm{pg} / \mathrm{ml}$, respectively). 


\section{Conclusions}

High levels of survivin are detected in the sera and synovial fluid of patients with RA and are associated with erosive joint damage and poor functional outcomes. Our findings support the role of survivin in the pathogenesis of RA. Further studies are needed on a larger group of RA patients follow-up to ascertain the erosive effect of survivin. Conduction of studies on survivin antagonist to evaluate their effect on ameliorating RA disease progression is recommended.

\section{Keywords:}

disease activity, erosion, rheumatoid arthritis, serum, synovial surviving

Egypt Rheumatol Rehabil 46:221-228

() 2019 Egyptian Society for Rheumatology and Rehabilitation

1110-161X

\section{Introduction}

Rheumatoid arthritis (RA) is a progressive debilitating autoimmune disease, affecting $1 \%$ of the world population, leading to cartilage and bone destruction caused by insufficient apoptosis in the inflamed RA synovium. Recent treatment has been revolutionized by the use of biologic therapies, such as drugs that target cytokines, cells, and signaling pathways [1,2].

Survivin is a proto-oncogene biomarker of cancer and may be found in most tumor tissues, such as lymphoma, colorectal carcinoma, breast cancer, and small cell and lung adenocarcinoma, where it predicts prognosis and the potential for metastasis [3]. Survivin is known for its anti-apoptotic function in the cytoplasmic and mitochondrial compartments by preventing activation of caspases and cell cycleregulating properties by aiding formation of a chromosomal passenger complex [4].

In healthy tissues, survivin expression is responsible for cell renewal and differentiation, being consistently expressed in thymocytes, bone marrow hematopoietic progenitors and stem cells, cells of the colon epithelium, and vascular endothelial cells [5].

Overexpression of survivin in noncancerous processes has been linked to inflammation, presumably contributing to decreased apoptosis in the $\mathrm{T}$ cells of cerebrospinal fluid in multiple sclerosis, in skin lesions of patients with psoriasis, and in synovial tissue of patients with RA [6].

In RA, survivin has abilities to inhibit apoptosis, promote cell proliferation, produce cytokines and growth factors, and promote the transformation of synovial fibroblasts to an invasive phenotype, followed by the proliferation of synovial tissue and pannus formation [1].

It is overexpressed in the preclinical phase of $\mathrm{RA}$, and together with antibodies to citrullinated peptides, is predictive for development of RA several years ahead of clinical symptoms [7]. In the presymptomatic stage of RA, survivin was associated with the pattern of regulatory cytokines [interleukin (IL)-12, IL-1, IL9, granulocyte-macrophage colony-stimulating factor, and IL-2], controlling the formation of pathogenic T helper (Th) 1 and Th17 lymphocytes [8].

Survivin is critical for the process of antigen presentation, the breaking point of immune responses in RA, being required for the expression of major histocompatibility complex class II molecule receptors on dendritic cells and for the formation of functional $\mathrm{T}$ cell receptors, and has been connected to the carriage of the human leukocyte antigen DRB1 genotype and smoking, important keystones in the pathogenesis of RA [9-13].

Expression of survivin in $\mathrm{B}$ cells might cause adverse cell recognition in RA, as changes in survivin expression after therapeutic B cell depletion was associated with a reduction of $B$ cell numbers, serum levels of rheumatoid factor (RF), and the activity of arthritis [6].

It has recently emerged as a biomarker of RA. High levels of survivin are associated with severe joint damage and poor treatment response [13].

\section{Patients and methods}

This study was carried out on 50 patients with RA attending the outpatient clinic and the inpatient department of Rheumatology, Rehabilitation and Physical Medicine of Benha University Hospitals. All of them met the updated American College of Rheumatology/European League Against Rheumatism criteria for the classification of RA [14].

Another 30 apparently healthy volunteers with a comparable age and sex were included as a control group. Verbal consent was taken from all participants included in the study, and it was approved by the 
Ethical Committee of Faculty of Medicine of Benha University on 6/2016.

(1) All patients were subjected to full history taking, thorough clinical examination, laboratory investigation, assessment of disease activity by disease activity score (DAS) 28 [15], and assessment of functional capacity and disability using Health Assessment Questionnaire (HAQ) [16]. Erythrocyte sedimentation rate was assessed by Westergren method, C-reactive protein (CRP) by latex agglutination slide test for qualitative and semiquantitative determination of CRP in nondiluted serum, RF by latex fixation test, and anti-citrullinated peptide antibody detected by enzyme-linked immunosorbent assay (ELISA).

(2) Serum and synovial survivin levels were measured by enzyme-linked immunosorbent assay by using a pair of matched antibodies (R\&D Systems, Abingdon, UK). Values of circulating survivin above $167.63 \mathrm{pg} / \mathrm{ml}$, corresponding to $3 \mathrm{SD}$ of a healthy control group, were defined as positive.

(3) Radiological assessment: plain radiographs of both hands $(\mathrm{P}-\mathrm{A})$ and $(\mathrm{A}-\mathrm{P})$ of feet were done. The presence of erosion was classified as an erosive disease and scored by Larsen score [17].

\section{Statistical analysis}

Using the computer program SPSS (statistical package for social science) version 16 , the collected data were summarized in terms of mean $\pm \mathrm{SD}$ and range for quantitative data and frequency and percentage for qualitative data. Comparisons between the different study groups were carried out using the $\chi^{2}$ test and Fisher exact test to compare proportions as appropriate. The Student $t$ test was used to detect mean difference between two groups regarding parametric data, whereas the Mann-Whitney test $(z)$ was used to compare nonparametric data.

\section{Results}

This study included 50 patients with RA, who had a mean age of $46.4 \pm 10.94$ years, comprising 39 females and 11 males, and 30 apparently healthy participant of matched age and sex to the patients, as a control group, with a mean age of $46.03 \pm 10.53$ years, comprising 23 females and 7 males. The clinical and laboratory variables of the patients with RA are shown in Tables 1 and 2.

Overall, 42/50 (84.5\%) of the patients with RA, whereas $8 / 30$ (2.6\%) of the controls were positive for RF. Moreover, 12/50 (24\%) of the patients with RA had
Table 1 The clinical characteristics of the patients with rheumatoid arthritis

\begin{tabular}{lcc}
\hline Variable & Mean \pm SD & Range \\
\hline Disease duration (years) & $9.1 \pm 7.36$ & $0.16-25$ \\
VAS $(0-10 \mathrm{~cm}$ ) & $4.63 \pm 1.38$ & $2-7$ \\
DAS28 & $5.11 \pm 0.9$ & $3.28-7.19$ \\
HAQ score (0-3) & $1 \pm 1.08$ & $0-3$ \\
Locomotor system & & \\
$\quad$ Duration of morning stiffness (h) & $1.42 \pm 0.94$ & $0.5-5$ \\
Number of tender joints & $12 \pm 6$ & $3-28$ \\
Number of swollen joints & $2 \pm 3$ & $0-14$ \\
Extra-articular manifestations $[n(\%)]$ & \multicolumn{2}{c}{$10(20)$} \\
Pleural effusion & \multicolumn{2}{c}{$5(10)$} \\
SC nodule & \multicolumn{2}{c}{$2(4)$} \\
Scleritis and episcleritis & \multicolumn{2}{c}{$13(26)$} \\
Sjogren syndrome & \multicolumn{2}{c}{$6(12)$} \\
Raynaud syndrome & \multicolumn{2}{c}{$1(2)$} \\
Vasculitis & $26(52)$ \\
Disease activity & $24(48)$ \\
Moderate & \multicolumn{2}{c}{ Severe }
\end{tabular}

DAS28, 28-joint disease activity score; $\mathrm{HAQ}$, Health Assessment Questionnaire; VAS, visual analog scale of pain.

Table 2 The laboratory characteristics of patients with rheumatoid arthritis

\begin{tabular}{lcc}
\hline Variables & Mean $\pm \mathrm{SD}$ & Range \\
\hline $\mathrm{Hb}(\mathrm{g} / \mathrm{dl})$ & $11.46 \pm 1.35$ & $8.3-14$ \\
Leukocytes (cell/ mcl) & $7.91 \pm 2.74$ & $3.6-15.5$ \\
$\mathrm{PLTs} / \mathrm{mcl}$ & $304733.3 \pm 117751.9$ & $170000-571000$ \\
$\mathrm{ESR}(\mathrm{mm} / 1 \mathrm{st} \mathrm{h})$ & $66.17 \pm 28.22$ & $0-120$ \\
$\mathrm{CRP}(\mathrm{mg} / \mathrm{dl})$ & $31.07 \pm 22.71$ & $6-96$ \\
\hline
\end{tabular}

CCP, cyclic citrullinated peptides; CRP, C-reactive protein; ESR, erythrocyte sedimentation rate; $\mathrm{Hb}$, hemoglobin; PLTs, platelet count.

anti-cyclic citrullinated peptides $(\mathrm{CCP})$ antibodies while all controls were negative for anti-CCP antibodies.

All patients with RA were on $200-400 \mathrm{mg} / \mathrm{d}$ hydroxychloroquine and weekly methotrexate injection $(15.9 \pm 2.01 / \mathrm{w}), 35$ patients were on oral prednisolone therapy $(7.6 \pm 2.6 \mathrm{mg} / \mathrm{dl})$, six patients were on $20 \mathrm{mg}$ leflunomide, and two patients were on sulphasalazine $(1.8 \pm 0.3 \mathrm{gm} / \mathrm{d})$.

The mean serum survivin level was highly statistically significantly elevated $(P<0.001)$ in the sera of the patients with RA than in the controls, being 239.1 \pm 115.15 and $77.03 \pm 30.20 \mathrm{pg} / \mathrm{ml}$, respectively. Synovial survivin levels were measured in the synovial fluid aspirated from 18 patients with RA who presented with knee effusion at the time of examination and ranged between 420 and $575 \mathrm{pg} / \mathrm{ml}$, with a mean of $479.61 \pm 52.68 \mathrm{pg} / \mathrm{ml}$, which was highly statistically significantly elevated than the mean serum survivin level in the patients with RA (Figs 1 and 2). 
Figure 1

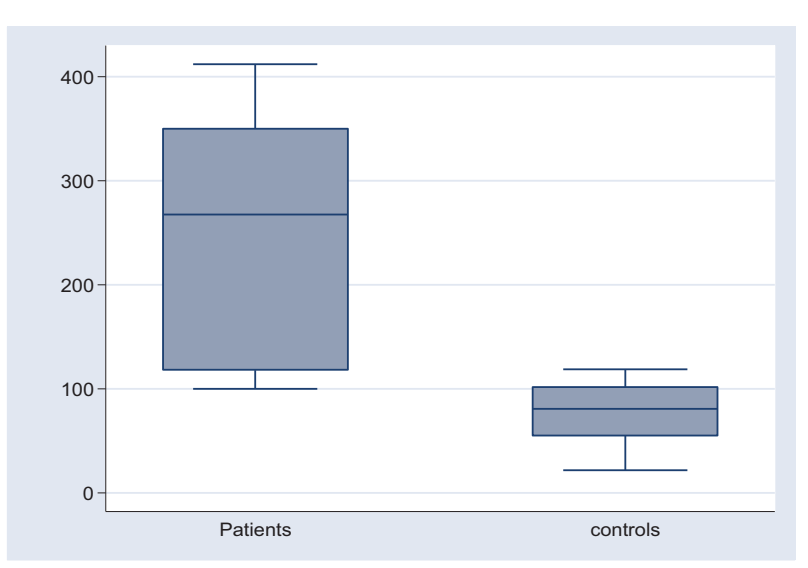

Comparison between mean serum survivin in the studied groups.

Figure 3

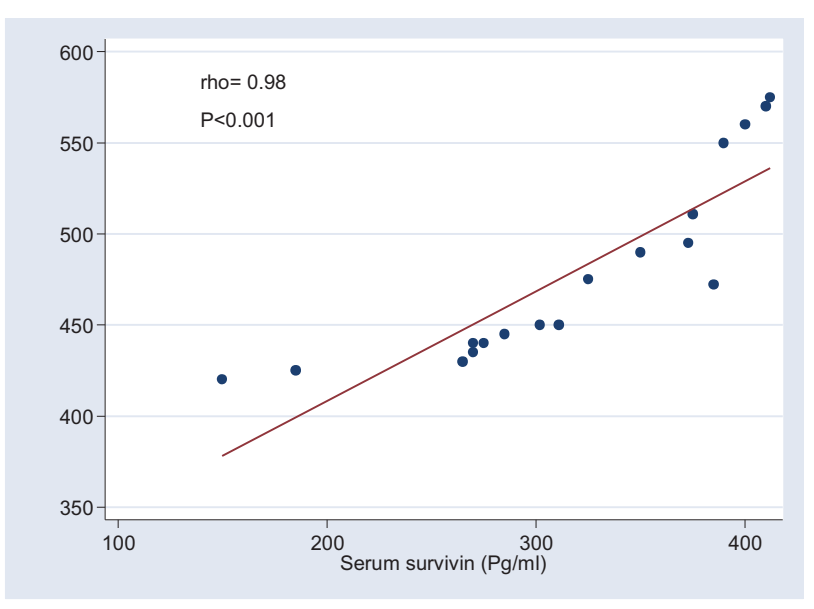

Both serum and synovial survivin levels were significantly positively correlated in the patients with RA group. RA, rheumatoid arthritis.

Both serum and synovial survivin levels were significantly positively correlated with disease duration $(r=0.8, P<0.001$ and $r=0.61, P<0.008)$, HAQ scores $\quad(r=0.93, \quad P<0.001$ and $r=0.94$, $P<0.001)$, and total Larsen scores $(r=0.96, P<0.001$ and $r=0.99, P<0.001)$. Serum survivin levels were highly statistically positively correlated with the synovial survivin levels $(r=0.98, P<0.001)$ (Fig. 3).

Patients were divided into two groups according to the serum survivin cutoff level, which was selected at the mean plus $3 \mathrm{SD}$ for the control group .Survivin -ve group included 21 (42\%) patients with RA with serum survivin level less than $167.63 \mathrm{pg} / \mathrm{ml}$ and survivin +ve group included 29 (58\%) patients with RA with serum survivin level more than or equal to $167.63 \mathrm{pg} / \mathrm{ml}$. Personal, clinical, and laboratory finding of the two groups are summarized in Table 3.
Figure 2

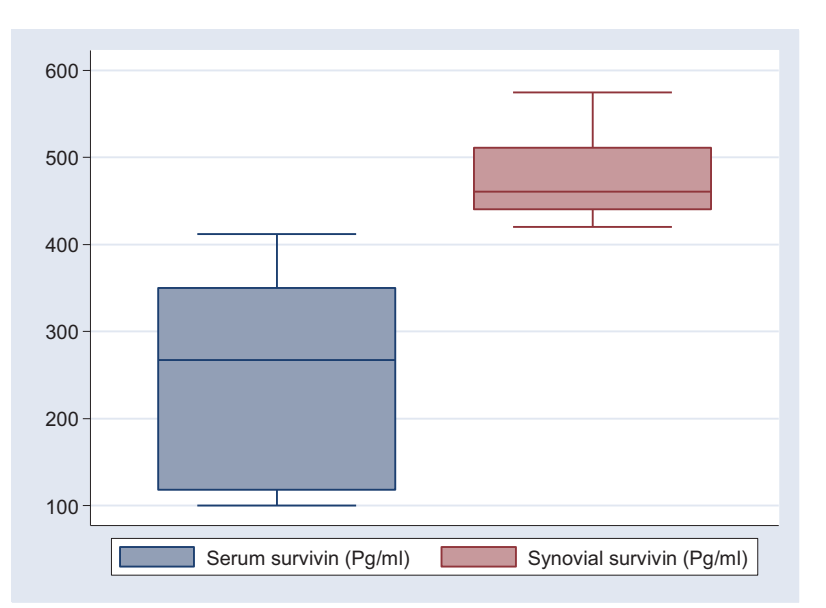

Comparison between mean serum and synovial surviving levels in the patients with RA group. RA, rheumatoid arthritis.

Survivin +ve patient group has significantly longer mean disease duration $(P<0.001)$, higher mean HAQ scores, and higher mean Larsen scores $(P<0.001)$ than survivin -ve patient group.

Overall, 9/13 (69.2\%) of the patients with RA with Sjogren's syndrome, 8/10 (80\%) of the patients with pleural effusion, 3/6 (50\%) patients with Raynaud's phenomenon, and all patients with SC nodules (5, $100 \%)$, episcleritis (2, 100\%), and vasculitis (1, 100\%) were survivin +ve.

Larsen scores of the patients with RA ranged from 0 to 65 , with a mean of $23.6 \pm 18.98$. Patients with $R A$ who had Larsen score grading more than or equal to two (27 (52\%) of 50 patients) were considered to have an erosive RA disease. All patients with RA with erosive disease (27) were survivin +ve, whereas no one of the survivin -ve group patients had an erosive disease. Patients with RA with erosive disease has statistically significantly elevated mean serum and synovial survivin values than the patients with $\mathrm{RA}$ with nonerosive disease $(P=0.03$ and $P<0.001)$ (Table 4).

There were no statistically significant differences between patients with erosive and nonerosive $\mathrm{RA}$ groups regarding age, sex, VAS values, DAS values, the presence of RF antibodies, anti-CCP antibodies, mean hemoglobin \%, leukocytic count, platelets count, erythrocyte sedimentation rate first hour values, or CRP levels.

\section{Discussion}

Survivin is expressed in active rheumatoid synovium. Its expression was confirmed histologically in the 
Table 3 Demographic, clinical, and laboratory characteristic of the patients with rheumatoid arthritis according to the serum survivin level

\begin{tabular}{|c|c|c|c|c|c|c|}
\hline Variables & \multicolumn{2}{|c|}{$\begin{array}{l}\text { Survivin negative }(<167.63 \mathrm{pg} / \mathrm{ml}) \\
\qquad(N=21,2 \%)[n(\%)]\end{array}$} & \multicolumn{2}{|c|}{$\begin{array}{c}\text { Survivin positive }(\geq 167.63 \mathrm{pg} / \mathrm{ml}) \\
(N=29,58 \%)[n(\%)]\end{array}$} & Test & $P$ \\
\hline \multicolumn{7}{|l|}{ Sex } \\
\hline Females & \multicolumn{2}{|c|}{$21(100.0)$} & \multicolumn{2}{|c|}{$18(62.1)$} & FET & 0.24 \\
\hline Males & \multicolumn{2}{|c|}{$0(0.0)$} & \multicolumn{2}{|c|}{$11(37.9)$} & & \\
\hline Age (years) (mean $\pm S D)$ & $47 \pm 12.16$ & $20-63$ & $45.94 \pm 10.27$ & $32-67$ & $t=0.26$ & 0.80 \\
\hline $\begin{array}{l}\text { Disease duration (years) (mean } \\
\pm \text { SD) }\end{array}$ & $3.38 \pm 2.91$ & $0.16-9$ & $13.47 \pm 6.7$ & $5-25$ & $t=4.05$ & $\begin{array}{c}<0.001 \\
(\mathrm{HS})\end{array}$ \\
\hline VAS & $5.08 \pm 1.11$ & $3-7$ & $4.29 \pm 1.49$ & $2-6$ & $t=1.58$ & 0.12 \\
\hline DAS28 & $5.15 \pm 0.74$ & $4.18-6.86$ & $5.07 \pm 1.03$ & $3.28-7.19$ & $t=0.25$ & 0.80 \\
\hline HAQ score & $0 \pm 0$ & 0 & $1.76 \pm 0.83$ & $0-3$ & $t=4.65$ & $\begin{array}{c}<0.001 \\
(\mathrm{HS})\end{array}$ \\
\hline \multicolumn{7}{|l|}{ Disease activity } \\
\hline Moderate & 11 & 52.38 & 15 & 51.72 & \multirow[t]{2}{*}{$\chi^{2}=0.002$} & \multirow[t]{2}{*}{0.96} \\
\hline Severe & 10 & 47.62 & 14 & 48.27 & & \\
\hline \multicolumn{7}{|l|}{ Locomotor system } \\
\hline $\begin{array}{l}\text { Duration of morning stiffness } \\
\text { (h) }\end{array}$ & $1.27 \pm 0.69$ & $0.5-3$ & $1.53 \pm 1.1$ & $0.5-5$ & $t=0.50$ & 0.62 \\
\hline Number of tender joints & $11.54 \pm 4.54$ & $5-18$ & 12.7 & $3-28$ & $t=0.45$ & 0.65 \\
\hline Number of swollen joints & $2 \pm 3.44$ & $0-12$ & $2.59 \pm 3.32$ & $0-14$ & $t=1.36$ & 0.17 \\
\hline Duration of treatment (years) & $1.6 \pm 1.55$ & $0.02-5$ & $3.97 \pm 4.49$ & $0.02-17$ & $t=1.61$ & 0.11 \\
\hline Erosion & \multicolumn{2}{|c|}{$0(0.0)$} & \multicolumn{2}{|c|}{$27(93.10)$} & $\chi^{2}=26.22$ & $\begin{array}{c}<0.001 \\
(\mathrm{HS})\end{array}$ \\
\hline Total Larsen score $\left(m^{2} a n \pm S D\right)$ & $6.54 \pm 6.79$ & $0-18$ & $36.65 \pm 14.19$ & $19-65$ & $t=7.04$ & $\begin{array}{l}<0.001 \\
(\mathrm{HS})\end{array}$ \\
\hline \multirow[t]{2}{*}{ Variable } & \multicolumn{2}{|c|}{$\begin{array}{l}\text { Survivin negative }(<167.63 \mathrm{pg} / \mathrm{ml}) \\
\qquad(N=21)\end{array}$} & \multicolumn{2}{|c|}{$\begin{array}{l}\text { Survivin positive }(\geq 167.63 \mathrm{pg} / \mathrm{ml}) \\
(N=29)\end{array}$} & Test & $P$ \\
\hline & Mean $\pm S D$ & Range & Mean $\pm D$ & Range & & \\
\hline $\mathrm{Hb}(\mathrm{g} / \mathrm{dl})$ & $11.23 \pm 1.44$ & 8.3-13.9 & $11.63 \pm 1.29$ & $9.4-14$ & $t=0.80$ & 0.43 \\
\hline Leukocytes (cell/mcl) & $8.01 \pm 2.93$ & $3.8-15.5$ & $7.83 \pm 2.67$ & $3.6-14.1$ & $t=0.17$ & 0.86 \\
\hline $\mathrm{PLTs} / \mathrm{mcl}$ & $\begin{array}{c}288153.8 \pm 107 \\
615.7\end{array}$ & $\begin{array}{c}180000-545 \\
000\end{array}$ & $\begin{array}{c}317411.8 \pm 126 \\
693.6\end{array}$ & $\begin{array}{c}170000-571 \\
000\end{array}$ & $t=0.54$ & 0.59 \\
\hline $\operatorname{ESR}(\mathrm{mm} / \mathrm{h})$ & $62.69 \pm 35.58$ & 0-120 & $68.82 \pm 21.83$ & $25-110$ & $t=0.58$ & 0.56 \\
\hline CRP (mg/dl) & $29.31 \pm 24.25$ & $6-96$ & $32.41 \pm 22.12$ & 6-96 & $t=0.6$ & 0.54 \\
\hline Synovial survivin (pg/ml) & $420(N=1)$ & 420 & $\begin{array}{l}\text { 483.12 } \pm 52.09 \\
\quad(N=17)\end{array}$ & $425-575$ & $t=1.64$ & 0.10 \\
\hline
\end{tabular}

CRP, C-reactive protein; DAS28, 28-joint disease activity score; ESR, erythrocyte sedimentation rate; FET, Fisher exact test; HAQ, Health Assessment Questionnaire; Hb, hemoglobin; HS, highly significant difference $(P<0.001)$; PLT, platelet. Significant difference $(P<0.05)$.

Table 4 Comparison between the mean serum and synovial survivin levels in patients with erosive and nonerosive rheumatoid arthritis

\begin{tabular}{|c|c|c|c|c|c|c|}
\hline \multirow[t]{2}{*}{ Variable } & \multicolumn{2}{|c|}{ Nonerosive RA $(n, \%=23,46 \%)$} & \multicolumn{2}{|c|}{ Erosive RA $(n, \%=27,52 \%)$} & \multirow[t]{2}{*}{ Test } & \multirow[t]{2}{*}{$P$} \\
\hline & Mean \pm SD & Range & Mean \pm SD & Range & & \\
\hline Serum survivin (pg/ml) & $126.78 \pm 24.33$ & $100-185$ & $337.37 \pm 55.19$ & $265-412$ & $t=4.66$ & $<0.001(\mathrm{HS})$ \\
\hline Synovial survivin (pg/ml) & $425 \pm 7.07(n=2)$ & $420-430$ & $486.44 \pm 51.9(n=16)$ & $425-575$ & $t=2.11$ & $0.03(\mathrm{~S})$ \\
\hline
\end{tabular}

HS, highly significant difference $(P<0.001)$; S, significant difference $(P<0.05)$; $t$, Student's $t$ test.

synovial tissues of patients with RA and was observed in the synovial tissue of collagen-induced arthritis animal model [18]. Considering that increased cell proliferation and resistance to apoptosis contribute to increased numbers of fibroblast-like synoviocytes and chronic inflammatory cells in rheumatoid joints, survivin has important implications for the pathogenesis of RA [19].
This study showed that the mean serum survivin levels were significantly elevated $(P<0.00)$ in the patients with RA compared with the healthy controls, being $239.1 \pm 115.15$ and $77.03 \pm 30.20 \mathrm{pg} / \mathrm{ml}$, respectively, and synovial survivin levels ranged between 420 and $575 \mathrm{pg} / \mathrm{ml}$, with a mean of $479.61 \pm 52.68 \mathrm{pg} / \mathrm{ml}$, which was statistically significantly higher than the mean serum survivin level in the patients with RA 
$(P<0.001)$. There was a positive relation between both serum and synovial levels.

This is consistent with previous observations found by Mahfouz et al. [20], who concluded that the mean serum survivin level for the RA group (335.0 $\pm 119.3 \mathrm{pg} /$ $\mathrm{ml})$ was significantly higher $(P<0.0000)$ than that for the controls $(161.0 \pm 55.2 \mathrm{pg} / \mathrm{ml})$, and it is close to that reported by Bokarewa et al. [21] who reported a survivin level of $121 \pm 2 \mathrm{pg} / \mathrm{ml}$ for the healthy individuals and a mean of $330 \pm 123 \mathrm{pg} / \mathrm{ml}$ in the RA group. Survivin is involved in many physiologic and pathologic steps in cellular response, metabolism, apoptosis, and cell cycle control [22]. Suppression of apoptosis has been suggested as a key mechanism supporting selection and accumulation of distinct lymphocyte subsets in chronically inflamed joint tissues [23]. Synovial T-cells in RA are highly differentiated and are not expected to survive for prolonged time within inflamed joints unless their death is actively inhibited [24].

The source of extracellular survivin in RA is not precisely identified. Possible sources include synovium itself, infiltrating cells in the synovial fluid, or circulating cells, such as leukocytes [22]. Bone marrow may be another potential source of survivin considering the fact that most of mononuclear cells of the peripheral blood continuously express survivin [21].

We found that survivin +ve patients with RA group has significantly longer mean disease duration $(P<0.001)$, higher $\mathrm{HAQ}_{2}$ and higher mean Larsen score $(P<0.001)$ than survivin -ve patients with RA group.

All patients with RA with erosive disease were survivin +ve and had statistically significantly elevated mean serum and synovial survivin levels than those patients with nonerosive disease.

Previous studies reported by Ahn et al. [22] and others found that patients with erosive RA showed higher levels of synovial fluid survivin than patients with nonerosive RA, and the level of survivin was related to radiologic Larsen scores and the severity of chronic inflammatory arthritis.

Bokarewa et al. [21] found a significant association of survivin with the tendency of erosion of the joint and concluded that patients with RA with high levels of survivin had a risk of joint destruction 16 times higher, compared with those with low levels of survivin.
High levels of survivin were reported in a crosssectional study of patients with juvenile RA and were associated with polyarticular and systemic onset of juvenile idiopathic arthritis (JIA) as well as with the active phase of the joint disease. This is of importance as the polyarticular/systemic type of arthritis and the inflammatory activity of JIA are important unfavorable prognostic parameters [25].

Apoptosis is a physiological process that mediates the programmed cell death controlling the regeneration of the tissues. Chronic inflammation in the joints is associated with an impaired apoptotic elimination of activated and autoreactive cells, resulting in hypertrophy of the inflamed synovia and the accumulation of inflammatory cells [26].

The results from the study conducted by Park et al. [27], provided evidence that survivin may promote synovial proliferation by stimulating angiogenesis.

The results by Chen et al. [1] showed that survivin helps the tumor-like proliferation of RA-fibroblastlike synoviocytes and is involved in the secretion of the proinflammatory cytokine IL-6 and MMPs. IL-6 promotes B-cell growth and differentiation, Th17 cell generation, and osteoclast formation [28]. MMP-9 was shown to be involved in the angiogenesis and the pannus formation in RA and to play pivotal roles in the development of synovial hyperplasia, sustained inflammation, and joint destruction, which has been considered as essential events in the development of RA [29].

On the contrary, in agreement with Ihn et al. [22], we did not find significant correlation between serum or synovial survivin in the patients with RA and disease activity assessed with DAS28, as DAS28 reflects the disease activity of RA at the systemic level rather than at the local joint level.Our results confirmed the results of Xing et al. [10], Bokarewa et al. [21], and Baran et al [30], who found a lack of direct correlation between serum survivin and inflammatory markers, including CRP and IL-6, which suggests a TNF-independent mechanism of survivin release.

This lack of correlation between survivin and inflammation was explained by Galeotti et al. [25] as it may be owing to different physiological mechanisms regulating survivin expression or owing to the different tissue origin of these proteins.

The nature of extracellular survivin release remains an enigma [31]. Active extracellular transport of survivin 
is described only as exosomal content [2]. Profound cellular disruption could be a cause of intermittent serum levels of survivin. Extracellular survivin has been shown to be biologically active, inducing surface expression of adhesion molecules on leukocytes of patients with RA [32], with a potential to regulate $\mathrm{T}$-cell functions and motility through a broad net of intracellular effectors [33]. At the preclinical stage of arthritis, serum survivin has been associated with the release of cytokines controlling the formation of Th cell subsets Th1 and Th17 [8]. Inhibition of survivin in experimental arthritis proved its intimate relation to the formation of effector $\mathrm{T}$ cells and to the system of matrix proteases in the inflamed joints [2]. The processes triggering and abrogating survivin release in RA could therefore pave a way to efficient therapeutic control of the disease.

\section{Conclusion}

High levels of survivin are detected in the sera and synovial fluid of patients with RA and are associated with erosive joint damage and poor functional outcomes. Our findings support the role of survivin in the pathogenesis of RA. Further studies are needed on a larger group of patients with RA with follow-up to ascertain the erosive effect of survivin. Conduction of studies on survivin antagonist to evaluate their effect on ameliorating RA disease progression is recommended.

\section{Financial support and sponsorship}

Nil.

\section{Conflicts of interest}

There are no conflicts of interest.

\section{References}

1 Chen D, Liu D, Liu D, He M, Peng A, Xu J, et al. Rheumatoid arthritis fibroblast-like synoviocyte suppression mediated by PTEN involves survivin gene silencing. Sci Rep 2017; 7:367.

2 Andersson KM, Svensson MN, Erlandsson MC, Jonsson IM, Bokarewa MI. Down-regulation of survivin alleviates experimental arthritis. J Leukoc Bio 2015; 97:135.

3 Gu YJ, Jin SD, Wang F, Hua YB, Yang L, Shu YQ, et al. Clinicopathological significance of $\mathrm{PI} 3 \mathrm{~K}$, Akt and survivin expression in gastric cancer. Biomed Pharmacother 2014; 68:471-475.

4 Athanasoula KC, Gogas H, Polonifi K, Vaiopoulos AG, Polyzos A Mantzourani M. Survivin beyond physiology: orchestration of multistep carcinogenesis and therapeutic potentials. Cancer Lett 2014 347:175-182.

5 Fukuda S, Pelus LM. Survivin, a cancer target with an emerging role in normal adult tissues. Mol Cancer Ther 2006; 5:1087-1098.

6 Turkkila M, Andersson KM, Amu S, Brisslert M, Erlandsson MC, Silfverswärd S, Bokarewa MI. Suppressed diversity of survivin splicing in active rheumatoid arthritis. Arthritis Res Ther 2015; 17:175.

7 Bokarewa M, Brink M, Erlandsson M, Rantapää Dahlqvist S. Survivin but not Fms-like tyrosine kinase 3 ligand is up-regulated before the onset of rheumatoid arthritis: a pilot study. Arthritis Res Ther 2014; 16:R45.
8 Levitsky A, Erlandsson MC, van Vollenhoven RF, Bokarewa MI. Serum survivin predicts responses to treatment in active rheumatoid arthritis: a post hoc analysis from the SWEFOT trial. BMC Med 2015; 13:247

9 Andersson SEM, Svensson MND, Erlandsson MC, Dehlin M, Andersson $\mathrm{KME}$, Bokarewa MI. Activation of Fms-like tyrosine kinase 3 signaling enhances survivin expression in a mouse model of rheumatoid arthritis. Plos One 2012; 7:e47668.

10 Xing Z, Conway EM, Kang C, Winoto A. Essential role of survivin, an inhibitor of apoptosis protein, in $\mathrm{T}$ cell development, maturation, and homeostasis. J Exp Med 2004; 199:69-80.

11 Kobayashi K, Hatano M, Otaki M, Ogasawara T, Tokuhisa T. Expression of a murine homologue of the inhibitor of apoptosis protein is related to cell proliferation. Proc Natl Acad Sci U S A 1999; 96:1457-1462.

12 Svensson B, Hafström I, Erlandsson MC, Forslind K, Bokarewa MI. Smoking in combination with antibodies to cyclic citrullinated peptides is associated with persistently high levels of survivin in early rheumatoid arthritis: a prospective cohort study. Arthritis Res Ther 2014; 16:R12.

13 Chun-Lai T, Murad S, Erlandsson MC, Hussein H, Sulaiman W, Dhaliwal JS, et al. Recognizing rheumatoid arthritis: oncoprotein survivin opens new possibilities: a population-based case-control study. Medicine (Baltimore) 2015; 94:e468.

14 Aletaha D, Neogi T, Silman AJ, Funovits J, Felson DT, Bingham COIII, et al Rheumatoid arthritis classification criteria: an American College of Rheumatology/European League Against Rheumatism collaborative initiative. Arthritis Rheum 2010; 62:2569-2581.

15 Prevoo ML, van 't Hof MA, Kuper HH, van Leeuwen MA, van de Putte LB, van Riel PL. Modified disease activity scores that include twenty-eight-joint counts. Development and validation in a prospective longitudinal study of patients with rheumatoid arthritis. Arthritis Rheum 1995; 38:44-48.

16 Bruce B, Fries J. The Stanford health assessment questionnaire (HAQ): a preview of its history, issues, progress, and documentation. J Rheumatol 2003; 30:167-178.

17 Larsen A. How to apply Larsen score in evaluating radiographs of rheumatoid arthritis in long term studies? J Rheumatol 1995; 22:1974-1975.

18 Hanashi M, Hayashi T, Saito T. Expression of survivin in synovium and cartilage in DBA/1 J mice with type II collagen-induced arthritis. Clin Exp Rheumatol 2005; 23:550.

19 Pope RM. Apoptosis as a therapeutic tool in rheumatoid arthritis. Nature Rev Immunol 2002; 2:527-535.

20 Mahfouz MM, EL-Satar HA, Rashed LaA. Serum survivin in patients with rheumatoid arthritis. Med J Cairo Univ 2010; 78:301-306.

21 Bokarewa M, Lindblad S, Bokarew D, Tarkowski A. Balance between survivin, a key member of the apoptosis inhibitorfamily, and its specific antibodies determines erosivity in rheumatoid arthritis. Arthritis Res Ther 2005; 7:R349-R358.

22 Ahn JK, Kim H, Lee J, Bae EK, Cha HS, Koh EM. Phenotypic characterization and invasive properties of synovial fluid-derived adherent cells in rheumatoid arthritis. Inflammation 2008; 31:365-371.

23 Hasunuma T, Kayagaki N, Asahara H, Mo-tokawa S, KobatA T, Yagita H, et al. Accumulation of soluble Fas inflamed joints of patients with rheumatoid arthritis. Arthritis Rheum 1997; 40:80-86.

24 Perlman H, Liu H, Georganas C, Koch AE, Shamiyeh E, Haines GKIII, Pope RM. Differential expression pattern of the antiapoptotic protein 2 and FLIP, in experimental arthritis. Arthritis Rheu 2001; 44:2899-2908.

25 Galeotti L, Adrian K, Berg S, Tarkowski A, Bokarewa M. Circulatingsurvivinindicatesseverecourse of juvenileidiopathicarthritis. Clin Exp Rheumatol 2008; 26:373-378.

26 Baier A, Meineckel I, Gay S, Pap T. Apoptosis in rheumatoid arthriti. Curr Opin Rheumatol 2003; 15:274-279.

27 Park MC, Chung SJ, Park YB, Lee SK. Relationship of angiogenic factors to disease activity and radiographic damage in rheumatoid arthritis. Clin Exp Rheumatol 2008; 26:881-886.

28 Maddur MS, Miossec P, Kaveri SV, Bayry J. Th17 cells: biology, pathogenesis of autoimmune and inflammatory diseases, and therapeutic strategies. Am J Pathol 2012; 181:8.

29 Qin S, Wang F, Zhou M, Ding W, Chen L, Lu Y. Immunolocalization of membrane-type $1 \mathrm{MMP}$ in human rheumatoid synovium tissues. Int $\mathrm{J}$ Clin Exp Pathol 2015; 8:9286.

30 Baran M, Mollers LN, Andersson S, Jonsson IM, Ekwall AK, Bjersing J, et al Survivin is an essential mediator of arthritis interacting with urokinase signalling. J Cell Mol Med 2009; 13:3797-3808. 
31 Erlandsson MC, Turkkila M, Siljehult F, Pullerits R, Eriksson C, RantapääDahlqvist S, Bokarewa MI. Survivin improves the early recognition of rheumatoid arthritis among patients with arthralgia: A population-based study within two university cities of Sweden. Semin Arthritis Rheum 2018; 47:778-785
32 Mera S, Magnusson M, Tarkowski A, Bokarewa M. Extracellular survivin upregulates adhesion molecules on the surface of leukocytes changing their reactivity pattern. J Leukoc Biol 2008;149-155.

33 Chen W, Zhu C. Mechanical regulation of T-cell functions. Immunol Rev 2013; 256:160-176. 